\title{
Harnessing wind energy on merchant ships: case study Flettner rotors onboard bulk carriers
}

\author{
Ibrahim S. Seddiek ${ }^{1}$ Nader R. Ammar ${ }^{2,3}$ \\ Received: 3 June 2020 / Accepted: 31 January 2021 / Published online: 25 February 2021 \\ (C) The Author(s), under exclusive licence to Springer-Verlag GmbH, DE part of Springer Nature 2021
}

\begin{abstract}
Shipping faces challenges of reducing the dependence on fossil fuels to align with the international regulations of ship emissions reduction. The maritime industry is in urgent need of searching about alternative energy sources for ships. This paper highlights the applicability of harnessing wind power for ships. Flettner rotors as a clean propulsion technology for commercial ships are introduced. As a case study, one of the bulk carrier ships operating between Damietta port in Egypt and Dunkirk port in France has been investigated. The results showed the high influence of the interaction between ship course and wind speed and direction on the net output power of Flettner rotors. The average net output power for each rotor will be $384 \mathrm{~kW} / \mathrm{h}$. Economically, the results reveal that the use of Flettner rotors will contribute to considerable savings, up to $22.28 \%$ of the annual ship's fuel consumption. The pay-back period of the proposed concept will be 6 years with a considerable value of levelized cost of energy. Environmentally, $\mathrm{NO}_{x}$ and $\mathrm{CO}_{2}$ emissions will be reduced by 270.4 and 9272 ton/year with cost-effectiveness of $\$ 1912$ and $\$ 55.8 /$ ton, respectively, at annual interest rate of $10 \%$.
\end{abstract}

Keywords Wind energy $\cdot$ Flettner rotor $\cdot$ IMO $\cdot$ Ship emission reduction $\cdot$ Cost-effectiveness

\section{Introduction}

More than $90 \%$ of the international trade is transported by ships (Jiang et al. 2018; Pasha et al. 2020). In year 2019, about 92,295 ships of 1.98 million deadweight shared in the maritime field activities, and more than 60,000 ships transported billions of tons of cargo worldwide (UNCTAD 2019). On the other hand, this growth contributed significantly to increasing the amount of emissions from ships. Annually, vessels emit

Responsible editor: Philippe Garrigues

Ibrahim S. Seddiek

prof.isibrahim@gmail.com

Nader R. Ammar

nammar@kau.edu.sa

1 Department of Marine Engineering Technology, College of Maritime Transport \& Technology, Arab Academy for Science, Technology \& Maritime Transport, Alexandria 1029, Egypt

2 Department of Marine Engineering, Faculty of Maritime Studies, King Abdulaziz University, Jeddah 21589, Saudi Arabia

3 Department of Naval Architecture and Marine Engineering, Faculty of Engineering, Alexandria University, Alexandria 21544, Egypt large quantities of pollutants into the air, principally in the form of nitrogen oxide $\left(\mathrm{NO}_{\mathrm{x}}\right)$, particulate matter $(\mathrm{PM})$, and sulfur oxide $\left(\mathrm{SO}_{x}\right)$, which have been steadily expanding and affect human health (Ammar and Seddiek 2018, 2020; Seddiek 2016). Latest statistics revealed that maritime transport is responsible for producing $3 \%$ of the world's total greenhouse gas emissions, contributing to global warming and extreme weather effects (Abdelkhalek et al. 2014; Bouman et al. 2017; Sadek and Elgohary 2020; Seddiek 2017; UNCTAD 2019).

In continuous steps, the International Maritime Organization (IMO) seeks to reduce the adverse effect of ship emissions by issuing the relative regulations within Annex VI of Marine Pollution Convention 78 (Ammar 2018, 2019a; Ammar and Seddiek 2017; Halff et al. 2018; IMO 2018, 2019). In addition to the international legislations, IMO pursues to urge those interested in the shipping industry to reach zero emissions ship either through the use of alternative fuels or a clean source of energy onboard ships (Ammar 2019b; Joung et al. 2020; Scott et al. 2017). Regarding alternative fuels, all practical studies and researches proved that LNG can be considered an alternative and possible solution to replace conventional fuels in maritime shipping as it shows the lowest cost compared with the other alternative technologies 
(Elgohary et al. 2014; Mohseni et al. 2019). With reference to new power sources, many research studies have been examining the applicability of using fuel cells, solar panels, and wind turbines to be a source of energy onboard ships (Clodic et al. 2018; Ghenai et al. 2019; Welaya et al. 2011; Welaya et al. 2013) .

Wind energy can be considered as an attractive option for marine applications. It is a renewable source and can be used in combination with low carbon fuels (Crist 2009; Parker 2013; Traut et al. 2014). The focus of the current paper is to evaluate the potential for Flettner rotor-powered ships. The literature review addresses the use of Flettner rotors in marine applications from the viewpoints of practical applications and researches. It was shown by De Marco et al. (2016) that Anton Flettner, in 1920, was the first engineer who studied the effectiveness of using Flettner rotors as ship propulsion system. Buckau ship is considered the first ship that enrolled this system in 1924 as a retrofit ship. Two years later, M/V Barbara became the first new build ship equipped by Flettner rotors (Seifert 2012). After a long time, in year 2010, Enercon, a wind energy company, launched a Flettner-powered cargo ship named E-Ship 1. Recently, two 30-m-tall rotor sails have been installed on a Maersk Tankers vessel (Norsepower 2015). Arief et al. (2018), Lele and Rao (2017), Searcy (2017), Seifert (2012), Talluri et al. (2018), and Traut et al. (2014) analyzed and evaluated the potential for implementing Flettner rotor systems for different ship types. As a step toward studying the applicability of the use of Flettner rotors in marine application, the present paper aims to analyze the Flettner rotor performance and to study the effect of different parameters on the turbine's net output power. These parameters include the effect of wind characteristics, ship speed, lift coefficient, motor speed, and rotation coefficient. In addition, a bulk carrier ship is investigated as a case study. An economic and environmental analysis for the case study is performed to evaluate the economic feasibility of Flettner rotors, levelized cost of energy, and their effectiveness in reducing ship emissions.

\section{Flettner rotors' principles and fundamentals}

In order to study the technical, environmental, and economic effects of using Flettner rotors onboard ships, the theoretical operation of these systems should be firstly presented. The main principle for the operation of Flettner rotors is the Magnus effect as shown in Fig. 1a (Lele and Rao 2017; Pearson 2014). It was first described by Heinrich Gustav Magnus in 1953 (Lele and Rao 2017; Talluri et al. 2018). The Magnus effect correlates with the velocity and pressure of a moving fluid (Gupta et al. 2017; Kray et al. 2014; Pezzotti et al. 2020). As the pressure of a moving fluid decreases, its velocity will be increased and vice versa. When induced wind current attacks a rotating cylinder, it retards the air on one direction and accelerates it on the opposite direction. Highand low-pressure regions will be formed around the rotating cylinder (Badalamenti and Prince 2008; Searcy 2017; Seifert 2012; Zdravkovich 1997). As a result of this pressure difference, lift and drag forces will be developed in the perpendicular and the parallel directions of the wind flow, respectively, as shown in Fig. $1 \mathrm{~b}$.

The produced lift and drag forces by the Magnus effect are a supporting mean for ship propulsion if a rotating cylinder is properly mounted onboard the ship. The rotation of the cylinder is controlled by an electric motor mounted onboard the ship. The power consumed by the motor and the thrust produced from the Flettner rotor will regulate the amount of the main engine power that can be replaced. The produced thrust can be calculated as the summation of the lift and drag forces in the ship direction (Ballini et al. 2017; Bentin et al. 2016; Bordogna et al. 2020; Bordogna et al. 2019; De Marco et al. 2016; Kray et al. 2012; Mittal and Kumar 2003; Traut et al. 2014).

\section{Flettner rotor modeling}

In this section, a simple technical, environmental, and economic modeling is presented. The modeling is divided in two subsections. The first section will present the technical model of the Flettner rotor. However, the second part illustrates the economic and environmental issues in case of using Flettner rotor onboard ships.

\section{Technical modeling}

For a moving vessel with a speed of $\left(V_{s}\right)$, the true wind speed and direction $\left(V_{t}, \gamma\right)$ will affect the Flettner rotor performance. This is because the changes in true wind direction to a moving vessel will result in a change in apparent wind speed $\left(V_{a}\right)$. Consequently, the apparent wind speed will affect Flettner rotor to generate the thrust in ship direction. Figure 2 illustrates the angles between ship and wind velocities as well as two coordinate systems. The $\left(X_{h}, Y_{h}, Z_{h}\right)$ coordinate system is used for the vessel hull, while $\left(X_{f}, Y_{f}, Z_{f}\right)$ is introduced for the course through the ocean.

The apparent wind speed $\left(\mathrm{V}_{\mathrm{a}}\right)$ can be calculated as a function of the vessel speed $\left(V_{s}\right)$ and the true wind speed $\left(V_{t}\right)$, as expressed in Eq. (1), assuming very small drift angle. In addition, its direction can be determined using Eq. (2):

$$
\begin{aligned}
& V_{a}=\sqrt{V_{t}^{2}+V_{s}^{2}-2 V_{t} V_{s} \cos \gamma} \\
& \beta=\cos ^{-1}\left(\frac{V_{t}^{2}-V_{a}^{2}-V_{s}^{2}}{-2 V_{a} V_{s}}\right)
\end{aligned}
$$


Fig. 1 Magnus effect (a) and schematic of the resulting lift and drag forces onboard a ship (b)

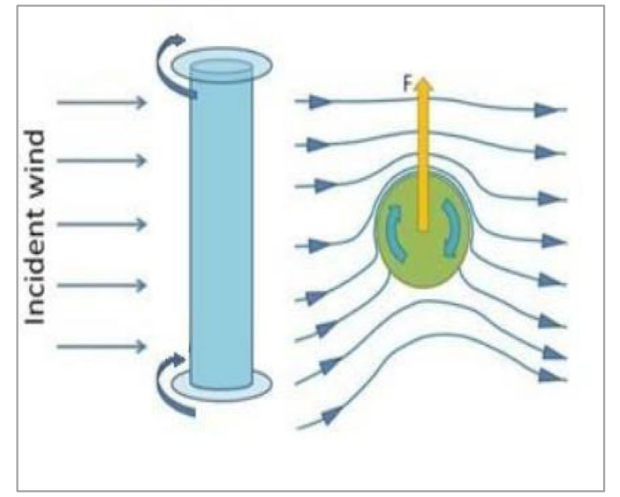

(a)

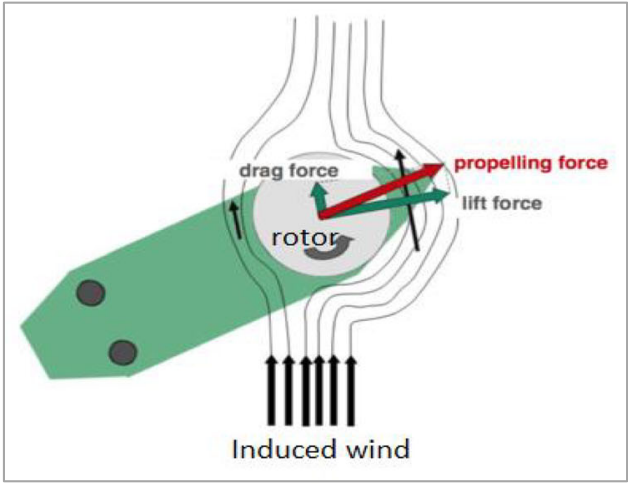

(b)
The rotational speed of the Flettner rotor has a great influence on the produced power. The rotors are assumed to be structurally connected to the ship hull. The rotation coefficient $\left(C_{\text {rot }}\right)$ is the ratio between the rotor rotational speed $\left(U_{\text {rot }}\right)$ and the apparent wind speed as expressed in Eq. (3):

$U_{\text {rot }}=C_{\text {rot }} \times V_{a}$

The flat plate boundary layer theory can be used to calculate the resistive force and the power required to overcome the skin friction of Flettner rotor system. Schlichting's formula can be used to calculate the skin friction coefficient as a function of Reynolds number. The power needed to turn the rotor $\left(P_{\text {con }}\right)$ and to overcome the friction force can be calculated using Eq. (4). It can be noted that this is an approximate assessment and additional aspects, as bearing roughness can also influence the required power:

$P_{\text {con }}=\left[\left(\frac{0.455}{(\log (R e))^{2.58}}-\frac{1700}{R e}\right) \times \rho_{a} \times \frac{U_{\text {rot }}^{2}}{2} \times A_{r}\right] \times U_{\text {rot }}$ where $\rho_{a}$ is the air density, $A_{r}$ is the surface area of the rotor, $R e$ is the Reynolds number. Re can be calculated using Eq. (5):

$R e=\frac{\rho_{A} \cdot C_{\mathrm{rot}} \cdot V_{a} \cdot L_{\mathrm{Re}}}{\mu}$

where $L_{\mathrm{Re}}$ is the characteristic length of rotor, and $\mu$ is the air dynamic viscosity.

To determine the effective power in ship direction $\left(P_{s}\right)$ and then the net output power of the Flettner rotor $\left(P_{\text {net }}\right)$, the lift and drag forces are resolved. $P_{S}$ and $P_{\text {net }}$ can be calculated considering the ship propulsion efficiency $\eta$ as expressed in Eqs. 6 and 7 (Lele and Rao 2017):

$$
\begin{aligned}
& P_{s}=\left(C_{L} \times \sin \beta-C_{D} \times \cos \beta\right) \times\left(\frac{\rho_{A} \times V_{a}^{2}}{2}\right) \times A \times V_{s} \\
& P_{\text {net }}=\left(P_{s}-P_{\text {con }}\right) \times \eta
\end{aligned}
$$

where $C_{L}$ is the lift coefficient, $C_{D}$ is the drag coefficient, and $A$ is the maximum wind-projected area of the Flettner rotor.

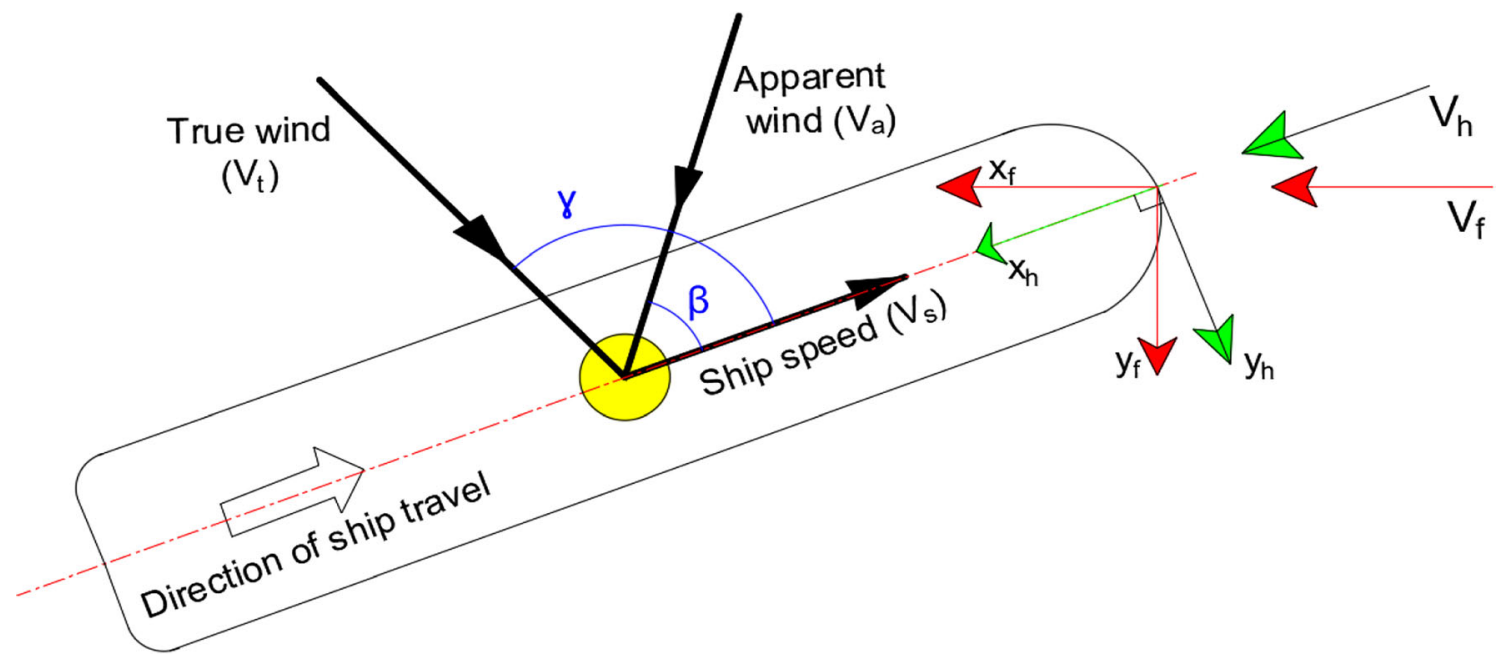

Fig. 2. Ship and wind velocity angles 
The lift and drag coefficients for each Flettner rotor can be calculated based on the numerical modeling as expressed in Eqs. 8 and 9:

$C_{L}=\sum_{i=1}^{4} \sum_{j=1}^{4} \sum_{k=1}^{3} a_{i j k} S R^{i} A R^{j}\left(\frac{d_{e}}{d}\right)^{k}$

$C_{D}=\sum_{i=1}^{4} \sum_{j=1}^{4} \sum_{k=1}^{3} b_{i j k} S R^{i} A R^{j}\left(\frac{d_{e}}{d}\right)^{k}$

where $S R$ and $A R$ are the spin and the aspect ratio of Flettner rotor. $\left(a_{i j k}\right)$ and $\left(b_{i j k}\right)$ are coefficients related to the geometrical and functional operations of Flettner rotors. Their values based on the fit procedure for the numerical results, as presented in De Marco et al. (2016). de/d is the large end plate and Flettner rotor diameter ratio. Equations 8 and 9 are valid for the following ranges: $1.0 \leq d e / d \leq 3.0,1.0 \leq \mathrm{SR} \leq$ 3.0 , and $2.0 \leq \mathrm{AR} \leq 8.0$.

The effect of the interaction between Flettner rotors on the flow field includes potential and viscous parts. The viscous section impact appears as wake and turbulence produced by flow separation and vortices. The circulation induced changes in the apparent wind speed and direction for each Flettner rotor. The analytical solution for the potential flow effects in the $x-y$ plane for a group of Flettner rotors is presented by Garzón and Figueroa (2017). The two components of the induced flow for each Flettner rotor in the $X$ and $Y$ directions, $V_{x}$ and $V_{y}$, can be calculated using Eqs. 10 and 11, respectively (Tillig and Ringsberg 2020):

$V_{x}=\frac{V_{\text {ind. }} \cdot r}{\sqrt{x^{2}+y^{2}}} \cos \left(\arctan \left(\frac{y}{x}\right)\right)$

$V_{y}=\frac{V_{\text {ind. }} \cdot r}{\sqrt{x^{2}+y^{2}}} \sin \left(\arctan \left(\frac{y}{x}\right)\right)$

where $r$ is the Flettner rotor radius, and $V_{\text {ind. }}$ is the induced velocity at each Flettner rotor. $V_{\text {ind. }}$ can be calculated as a function of the rotor circulation $\Omega$. The circulation can be calculated using known lift coefficients $\left(C_{L}\right)$ using KuttaJoukowsky formula or from model tests (Abbot and Von Doenhoff 1959; Bordogna et al. 2020). The relation between $V_{\text {ind., }} \Omega$, and, $C_{L}$ is given in Eqs. 12 and 13 (Houghton et al. 2017; Swanson 1961):

$\Omega=2 \pi r V_{\text {ind }}$

$C_{L}=\left(1-R_{c}\right)\left(\frac{\Omega}{r V_{a}}\right)+\frac{R_{c} \sin (\gamma)}{2 \pi}\left(\frac{\Omega}{r V_{a}}\right)^{2}$

where, $R_{c}$ presents the ratio between the Flettner rotor radius $(r)$ and the distance to the external vortex and $(\gamma)$ is the vortex direction. The values of $R_{c}$ and $\gamma$ according to model tests are 0.25 and $210^{\circ}$, respectively, in the range of $1.0 \leq \mathrm{SR} \leq$ 4.0 .

\section{Environmental and economic modeling}

To evaluate the environmental benefits in case of using Flettner rotors, the annual ship fuel saving $\left(A F S_{F R}\right)$ is calculated using Eq. 14. It depends on the saved propulsion power during the trip $\left(P_{F R}\right)$ in $\mathrm{kW}$, specific fuel consumption of the main diesel engine $\left(S F C_{M E}\right)$ in $\mathrm{kg} / \mathrm{kWh}$, the sailing hours per year $(H)$, and number of Flettner rotors $\left(N_{F R}\right)$.

$A F S_{F R}=\sum_{i=1}^{i=n} N_{F R} \times P_{F R} \times S F C F_{M E} \times H$

The annual reduction in emissions due to using Flettner rotors $\left(A E R_{F R S}\right)$ can be calculated using Eq. 15 (Ammar 2018; Ammar and Seddiek 2017, 2018, 2020):

$A E R_{F R}=\sum_{i=1}^{i=n} N_{F R} \cdot P_{F R} \cdot F_{e} \cdot H$

where $F_{e}$ is the emission factors for the engine in $\mathrm{g} / \mathrm{kWh}$. These factors for slow speed marine diesel engine operated with heavy fuel oil are 18.1, 10.29, 1.4, 620.62, 0.6, and 1.42 $\mathrm{g} / \mathrm{kWh}$ corresponding to $\mathrm{NO}_{x}, \mathrm{SO}_{x}, \mathrm{CO}, \mathrm{CO}_{2}, \mathrm{HC}$, and $\mathrm{PM}$ emissions, respectively (IMO 2018, 2019).

From an economic point of view, the annual Flettner turbines cost (AFTC) will depend mainly on the initial, installation, operation, and maintenance cost and could be estimated as shown in Eq. (16):

$$
\begin{aligned}
A F T C= & \frac{(1+i)^{n}}{(1+i)^{n}-1}\left[N_{F R} \times C C+\sum_{y=1}^{y=u} C_{y} D_{y}\right] \\
& +\left[P_{c o n} \cdot S F C_{A E} \times F_{c} \times 10^{-3}+C_{O \& M}\right] \times N_{F R} \\
& \times H
\end{aligned}
$$

where $i$ is interest rate, $n$ is the expected ship's working year after installation of turbines, $C C$ is the initial cost of one rotor in USD per unit, $C_{y} D_{y}$ is the installation cost of one rotor in USD, $P_{\cos }$ is the power consumed for Flettner rotor in $\mathrm{kW}$ for one rotor, $S F C_{A E}$ is diesel generator-specific fuel consumption in $\mathrm{kg}$ per $\mathrm{kW}, F_{c}$ is fuel cost in USD per ton, and $C_{\mathrm{O \& M}}$ is the maintenance and operation cost in USD per hour. On the other hand, the optimistic effect of Flettner turbines appears in the form of annual saving cost (AFTSC), which may be determined as follows:

$A F T S C=P_{F R} \times N_{F R} \times S F C_{M E} \times F_{c} \times(1 \pm p)^{\mathrm{n}} \times H \times 10^{-3}$

where, $p$ is the expected increasing or reducing percent of fuel cost. Moreover, it preferred to estimate the levelized cost 
of energy (LCOE) as an indication of importance of applying the proposed concept realistically. This parameter is widely used, and it was presented by the International Renewable Energy Agency (IRENA), which formulated it to be expressed as follows (Aldersey-Williams and Rubert 2019):

$\mathrm{LCOE}=\frac{\sum_{t=1}^{x} \frac{I_{t}+M_{t}+F_{t}}{(1+r)^{t}}}{\sum_{t=1}^{x} \frac{E_{t}}{(1+r)^{t}}}$

where $x$ is the number of years of the investment period, $t$ is one of the years during period $x, I_{t}$ is capital expenditures costs (CAPEX) in year $(t), \mathrm{M}_{\mathrm{t}}$ is operation and maintenance expenses costs (OPEX) in year $(t), F_{t}$ is the fuel cost in year $(t) . E_{t}$ is the number of Megawatt hours generated by the Flettner rotors during year $t$, and $r$ is the discount rate.

It is important to combine the environmental benefits that can be achieved through the application of Flettner turbines technique onboard ships and the costs involved in this application. To calculate the cost-effectiveness $\left(C E_{\mathrm{em}}\right)$ in dollars per ton, the annual costs of the project are divided by the annual quantity of emission reduced as a result of this proposal, as follows (Ammar 2019b; Ammar and Seddiek 2017, 2018):

$C E_{\text {em }}=\frac{(A C V-A S V)}{E R_{q}}$

where $A C V$ is the annual cost value of the proposed Flettner rotors (\$/year), $A S V$ is the annual fuel saving ( $\$$ year), and $E R_{q}$ is the annual emission reduction for each species of exhaust gases in ton/year.

\section{Case study}

Wadi Alkarm (IMO: 9460760) is a bulk carrier ship that was built in 2011. The ship is registered in Alexandria port with registry number of 3633 under the Egyptian flag. The principal dimensions of the ship length, breadth, and draft are 229 $\mathrm{m}, 32 \mathrm{~m}$, and $14.46 \mathrm{~m}$, respectively. The dead weight of the ship is 80,533 MT with a total gross tonnage of 43,736 MT. The transported cargo includes coal, iron, ore, and grain with Suez Canal gross and net tonnages of 45,016 MT and 40,414 MT, respectively. The main technical data for the case study can be summarized in Table 1 (FleetMon 2020; Marine Traffic 2020).

$\mathrm{M} / \mathrm{V}$ Wadi-Alkaram sails in a route from Damietta port in Egypt to Dunkirk port in France. Figure 3 shows the ship directions that changed at Tunisia, Algeria, Morocco, Spain, and Portugal. With average speed of 13 knots, the ship takes about 13 to 15 days for one route.
Table 1 Main technical data for the case study ship

\begin{tabular}{ll}
\hline Vessel name & Wadi Alkarm \\
\hline IMO number & 9460760 \\
Length & $229 \mathrm{~m}$ \\
Breadth & $32 \mathrm{~m}$ \\
Draft & $14.46 \mathrm{~m}$ \\
Gross tonnage & $43,736 \mathrm{MT}$ \\
Service speed, knots & 13.5 \\
Main engine type & MAN B\&W \\
Number of cylinders & $7 \mathrm{~S} 50 \mathrm{MC}-\mathrm{C}(\mathrm{MK}$ VII) \\
NCR (continuous running) & $13,545 \mathrm{BHP}$ X 123 RPM \\
Diesel generators & $3 \times 625 \mathrm{~kW}$ at $1200 \mathrm{RPM}$ \\
Number of trips per year & 10 \\
\hline
\end{tabular}

Figure 4 illustrates the proposed locations of four Flettner rotors on the ship's main deck. The rotors will be distributed along the ship length, specifically at port and starboard of hatches number 2 and 4 . The rotors will be installed in the way that lets free moving for crew to carry out the necessary operations and maintenance activities on the main deck, and it will not hinder the loading and unloading of the cargo. In terms of the possibility of installation, the bulk carrier ships are considered one of the most suitable ships for installing this type of turbines, as there are no winches on the surface where the goods are loading and unloaded, whether by external winches or by belts.

The selected Flettner rotor model to be installed onboard the case study is the Norsepower rotor (Norsepower 2018). The rotors are installed onboard the ship on foundation with a bolt connection and height of $2.5 \mathrm{~m}$. The rotor height and diameter are $24 \mathrm{~m}$ and $4 \mathrm{~m}$, respectively. The total weight of the rotor including the foundation is 34 tons. The supported tower for the rotor is a cylindrical steel structure. The variable rotor speed changes from 0 to $225 \mathrm{rpm}$ with $90 \mathrm{~kW}$ electric motor drive. The operational wind speed range for the rotor starts from 0 to $25 \mathrm{~m} / \mathrm{s}$ with a survival wind speed of $70 \mathrm{~m} / \mathrm{s}$ and a maximum continuous thrust of $175 \mathrm{kN}$.

The following assumptions are made for simplicity regarding ship route, ship stability, and wind speed and direction. The investigated ship is assumed to travel on a fixed route at constant speed from Damietta port to Dunkirk port. The installation of the Flettner rotors will not have an effective impact on ship stability and displacement. The initial calculations for the Flettner rotor technical results are performed at ship speed of 13.5 knots, during cruise in the open sea, over true wind angles from $0^{\circ}$ to $360^{\circ}$. Both ship drift angle and bearing friction are neglected. The ship propulsion system efficiency is assumed to be 60\% (Lele and Rao 2017; Tillig and Ringsberg 2020; Traut et al. 2014). The values for the air density and dynamic viscosity are assumed $1.225 \mathrm{~kg} / \mathrm{m}^{3}$ and 


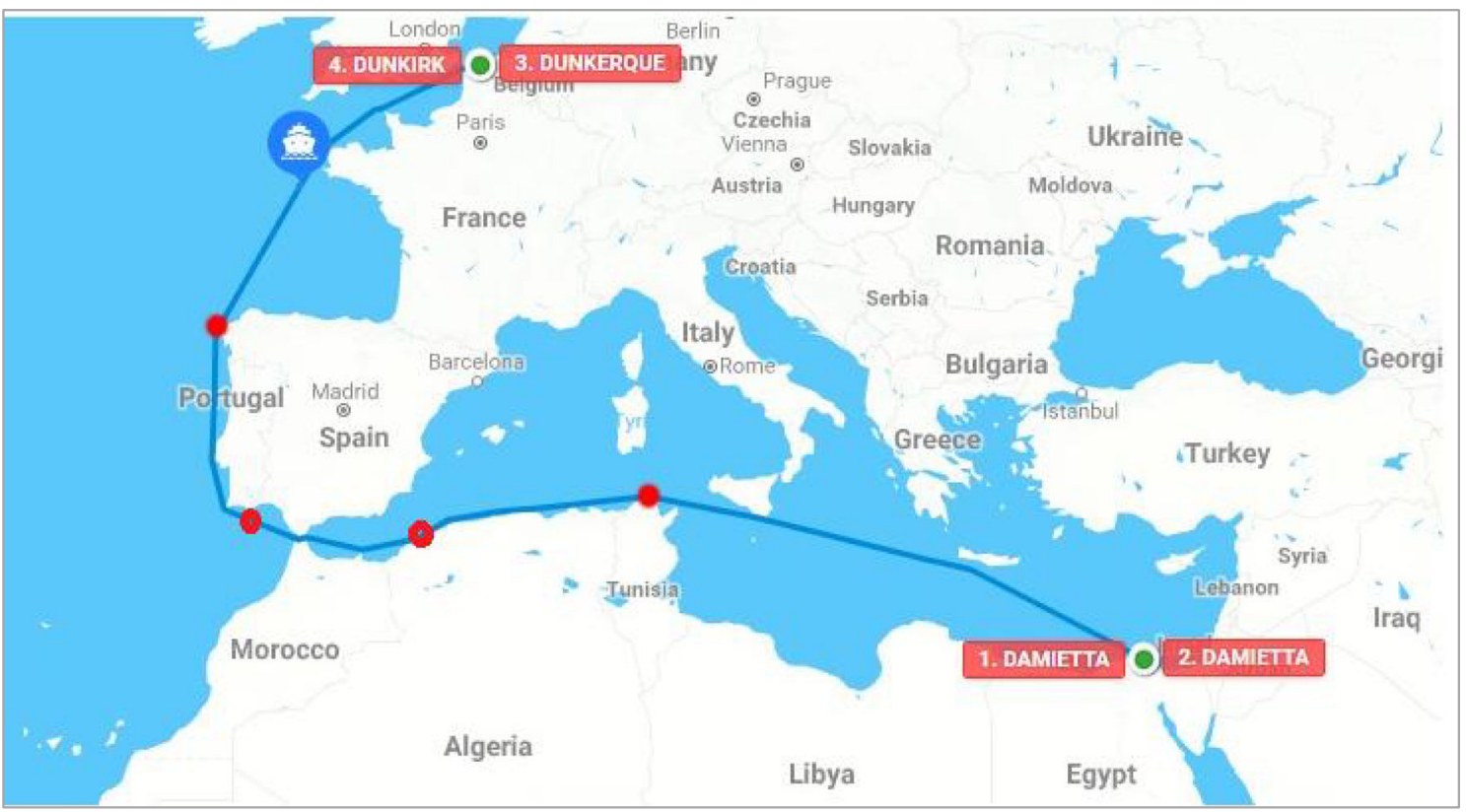

Fig. 3 Ship's route and passing points

$1.789 \times 10^{-5} \mathrm{~N}-\mathrm{m} / \mathrm{s}^{2}$, respectively (Cimbala and Çengel 2013; Nakayama and Boucher 1998a). Schlichting's equation is used for calculating friction coefficient (Munson et al. 2012; Nakayama and Boucher 1998b). The data for wind speed and direction were based on the meteoblue climate statistics (Meteoblue 2020).

\section{Results and discussion}

In this section, the technical, environmental, and economic results for using Flettner rotor onboard the selected case study are presented. The results imply the effect of wind speed variation, ship's speed, lift coefficient, motor speed, and rotation coefficient on the net output power of Flettner rotors. In addition, the environmental and economic effects of using Flettner rotor onboard the case study are discussed.

\section{Technical and environmental results}

It is important to include the aerodynamic interaction effects among different Flettner rotors when studying their performance onboard a ship. The potential part of this interaction is dominating as the apparent wind speeds and directions are changed according to the induced circulation (Tillig and Ringsberg 2020). The apparent wind speed and direction at each rotor is highly affected by the position and the circulation of the other rotors. Therefore, the lift and drag coefficients, as well as the optimum rpm, should be calculated according to the characteristics of the experienced wind speed and
Fig. 4 Flettner rotors locations onboard the case study

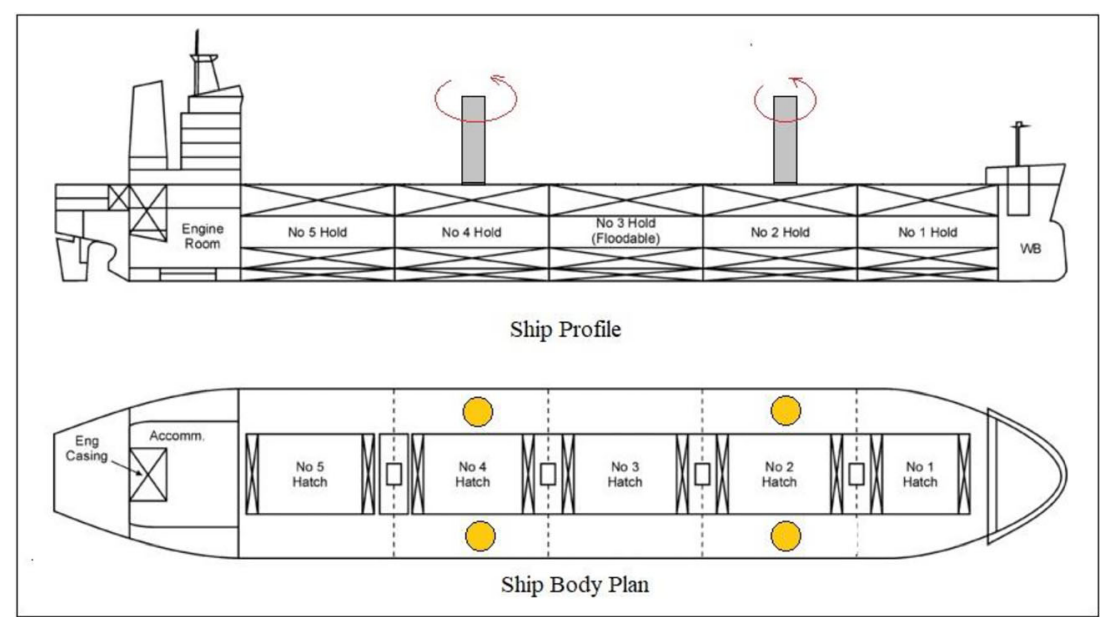




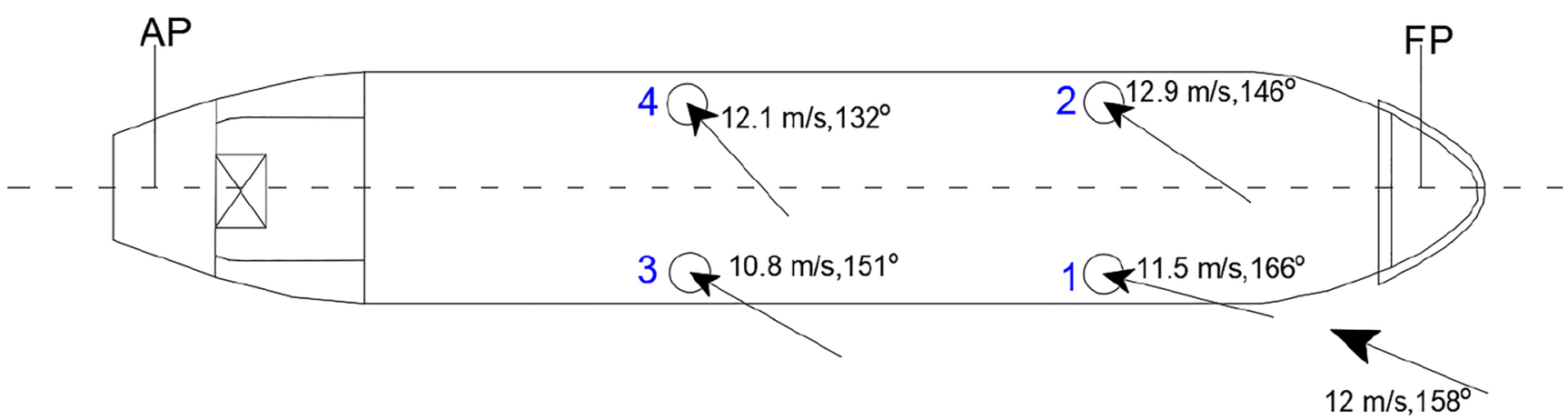

Fig. 5 The apparent wind speeds and directions for the four rotors at ship speed of $13.5 \mathrm{knots}, V_{t}=6.5 \mathrm{~m} / \mathrm{s}$, and $\gamma=225^{\circ}$

directions. The wind speeds and angles agree with these practices by sail boats at various locations in a fleet (Bethwaite 2013). The optimum rpm for each rotor is calculated according to wind speed, wind direction, and the induced velocity at each rotor, and the preferred spin ratio ranges from 1.0 to 3.0 for marine applications (De Marco et al. 2016). To show the interaction effects of the installed four Flettner rotors, the induced flow field for the case study, at $V_{s}=13.5$ knots and $V_{t}=$ $6.5 \mathrm{~m} / \mathrm{s}$, is illustrated in Fig. 5. The induced flow is calculated using MATLAB program, according to Eqs. 10-13, at true wind angle of $225^{\circ}\left(V_{a}=12 \mathrm{~m} / \mathrm{s}, \beta=158^{\circ}\right)$. The longitudinal and transverse distances between rotors are $65 \mathrm{~m}$ and $25 \mathrm{~m}$, respectively. In addition, the apparent wind speeds and directions at each rotor are shown in Fig. 5, considering the different interaction among the four rotors.

Among the important parameters that define Flettner rotor performance are the lift and drag coefficients which can be calculated using Eqs. 8 and 9. They determine the lift and drag forces generated and consequently the system effective forces in ship direction and perpendicular to it. Figure 6 shows the effective forces in ship direction for the four Flettner rotors, organized according to Fig. 5, considering the aerodynamic effects with and without interaction. The effective force values are calculated at optimum rpm for each rotor whose diameter and height are $4 \mathrm{~m}$ and $24 \mathrm{~m}$, respectively. These dimensions are consistent with the ship taken into consideration. The calculations are performed at ship speed of 13.5 knots, according to the wind characteristics of the route for the case study. The aim of these considerations is a rough evaluation of the potentiality of the Flettner rotors as a marine propulsion device. It can be noticed that the forward Flettner rotors 1 and 2 benefit from the interaction, while the aft rotors 3 and 4 suffer from it. In addition, the side force produced from each Flettner rotor is augmented as a result of flow interactions.

The net output power of each Flettner rotor with and without aerodynamic interaction, organized according to Fig. 5, can be presented in a polar plot as shown in Fig. 7. It explains the variation rotor's net power output because of change of the true wind speed from 5 to $25 \mathrm{~m} / \mathrm{s}$. The other variables including lift and drag coefficients change for each rotor according to its circulation and spin ratio. It can be noticed that the rotor power consumption is increased as the wind velocity increases. The net output is positive as the thrust generated is higher than the resistive force. The net output power depends on the wind characteristics and ship speed. Figure $7 \mathrm{a}$ and $\mathrm{b}$ show the effect of reducing ship speed from 13.5 knots to 10 knots on the net output power at different wind characteristics. The results are identical for the positive and negative angles
Fig. 6 Effective force in ship direction from the four Flettner rotors with and without interaction at ship speed of 13.5 knots

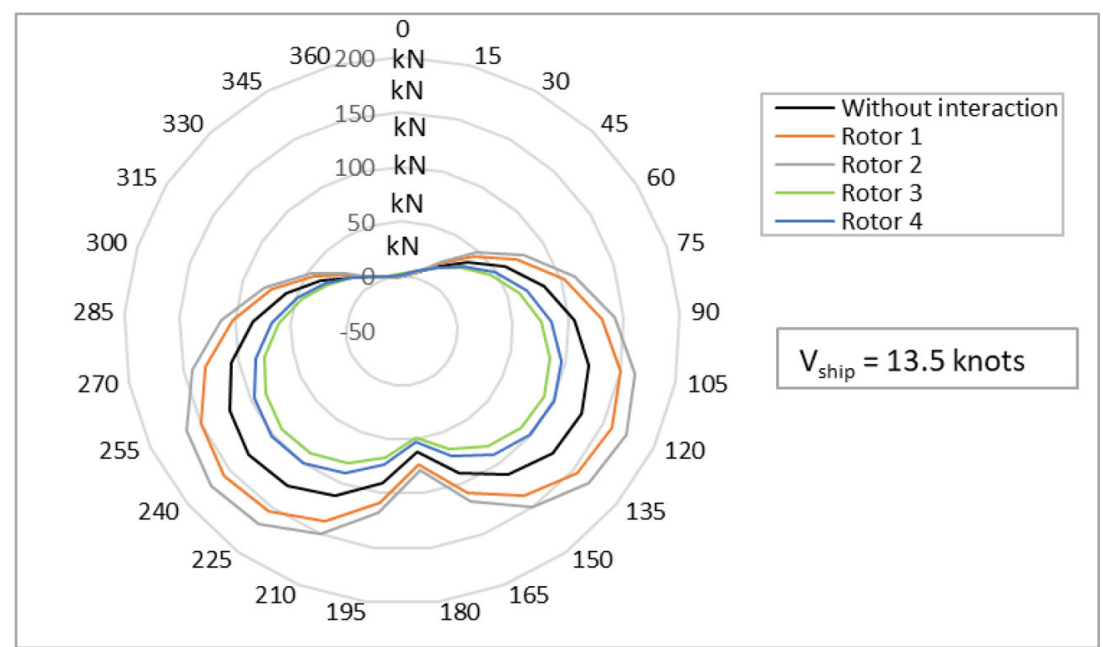


Fig. 7 Flettner rotor net power variation with true wind characteristics and ship speeds of 13.5 knots (a) and 10 knots (b)

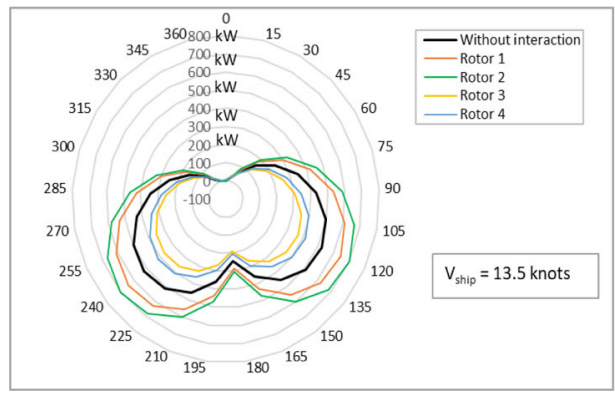

(a)

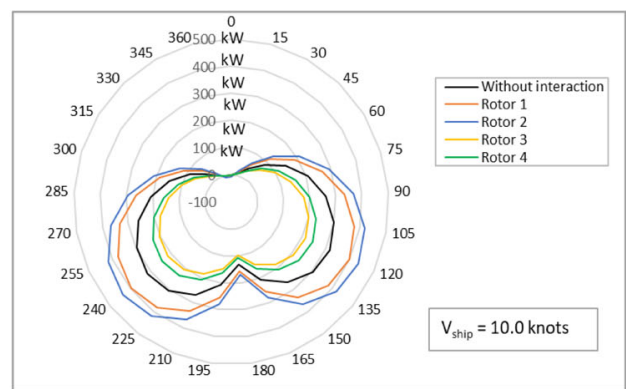

(b) because of the symmetric characteristics of the net output power. The highest values of the net out power for the selected Flettner rotor can be obtained at true wind speeds higher than $22 \mathrm{~m} / \mathrm{s}$ over ranges of wind angles from 105 to 135 degrees and from 225 to 255 degrees. The maximum net output power, shown in Fig. 7, is reduced from 704 to $437.5 \mathrm{~kW}$ at true wind directions of $120^{\circ}$ and $240^{\circ}$ when the ship speed is reduced from 13.5 to 10 knots.

The speed of the rotor determines the required power for its operation which affects the net output power of the Flettner rotor. Figure 8 shows the effect of coefficient of Flettner rotor rotation, organized according to Fig. 5, on the net output power for the four rotors considering the aerodynamic interaction among them. The figure is drawn at an average rpm of 80 for the four rotors considering wind speed, wind direction, the induced velocity at each rotor, and different spin ratio for each rotor. As the coefficient of rotation increases, the net output power will be reduced due to the increased power required for rotor rotation. In contrast, the net output power is increased at low rotational coefficient values.

To evaluate the environmental benefits of the Flettner rotors, the annul fuel saving is calculated based on the saved propulsion power. Using wind data available in the meteoblue climate data (Meteoblue 2020), the total annual fuel saving, from the four rotors, can be calculated as shown in Fig. 9. It shows the annual fuel saving based on the ship route and wind characteristics all over the year. The highest annual fuel saving, from Fig. 9, is 3528 ton/year achieved in January. On the other hand, the lowest annual fuel saving will be 223 ton corresponding to October wind characteristic data. The average net output power for the ship route all over the year based on wind speed, direction, and ship course is $1537 \mathrm{~kW}$ with an average annual fuel saving of 1693 ton/year for the used four rotors. Finally, using four Flettner rotors will lead to saving in ship fuel consumptions by $22.28 \%$.

From the calculated values of the annual fuel saving due to using Flettner rotors, the annual emission reduction can be estimated. Figure 10 shows the values of the reduced $\mathrm{NO}_{x}$, $\mathrm{SO}_{x}, \mathrm{CO}, \mathrm{CO}_{2}$, and $\mathrm{HC}$ at true wind angles from $0^{\circ}$ to $360^{\circ}$ and ship speed of 13.5 knots. These values are calculated for the four Flettner rotors, according to the wind characteristics of the route for the case study. The highest emission reduction can be achieved at true wind angles of $120^{\circ}$ and $240^{\circ}$. This is due to the increased rotor's lift force and the net output power. In contrast, the lowest reduction values will be at wind angles of $0^{\circ}$ and $360^{\circ}$.

The actual amount of reduced emissions due to using the Flettner rotor onboard the selected case study, based on the ship route from Damietta to Dunkirk ports, is shown in Fig. 11. The higher the value of emission reduction, the more environmental benefits will be gained. The highest annual emission reduction rate is 9272 ton/year for reducing $\mathrm{CO}_{2}$
Fig. 8 Coefficient of rotation effect on the Flettner rotors net power

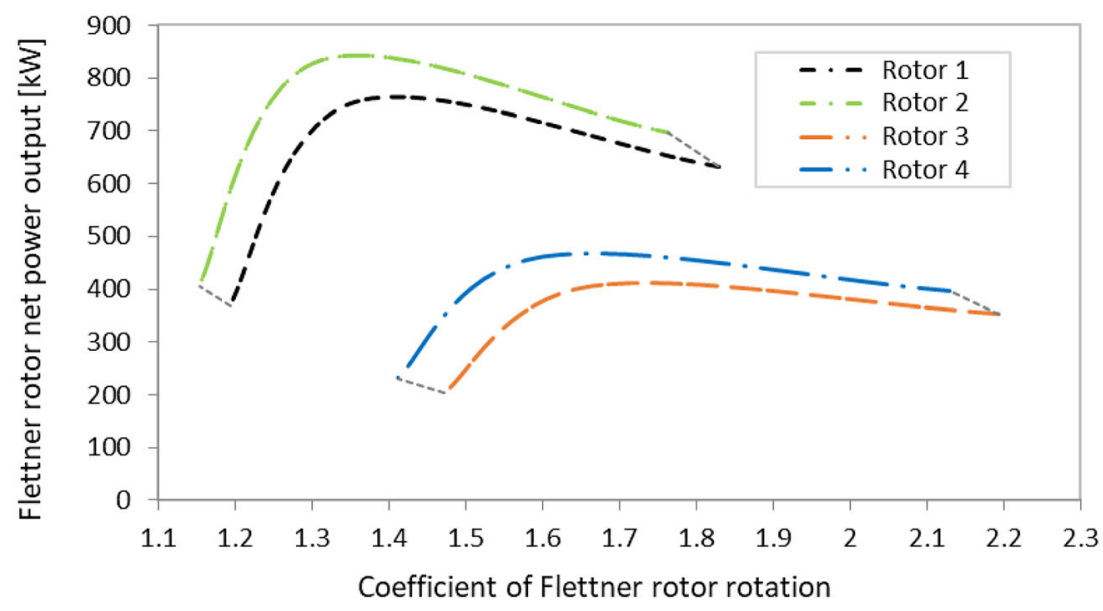


Fig. 9 Average annual fuel saving based on ship route and true wind speed and direction
Fig. 10 Emission reduction due to using Flettner rotor model at different wind angles
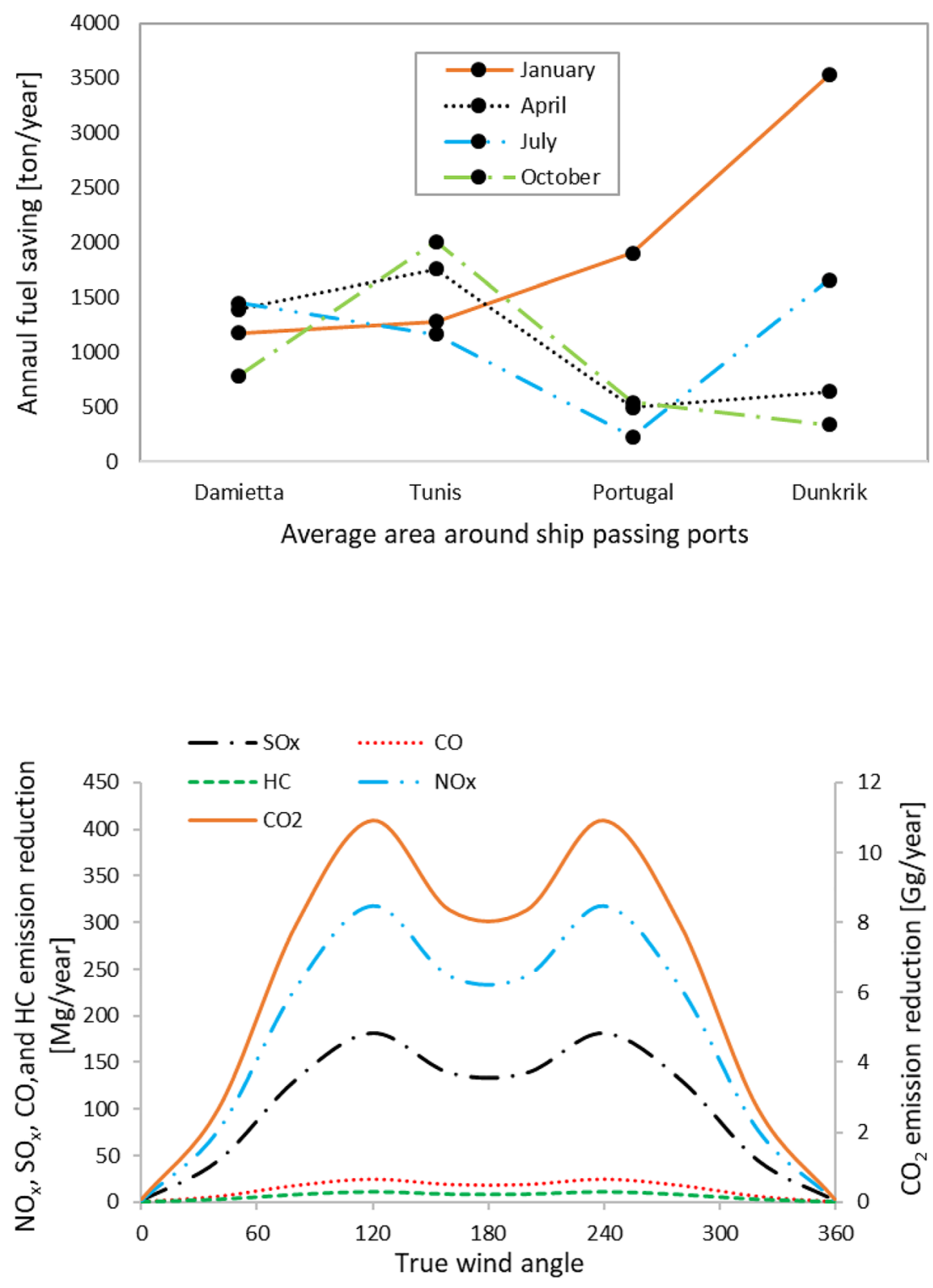

Fig. 11 Environmental benefits due to using four Flettner rotor models onboard the case study at ship speed of 13.5 knots

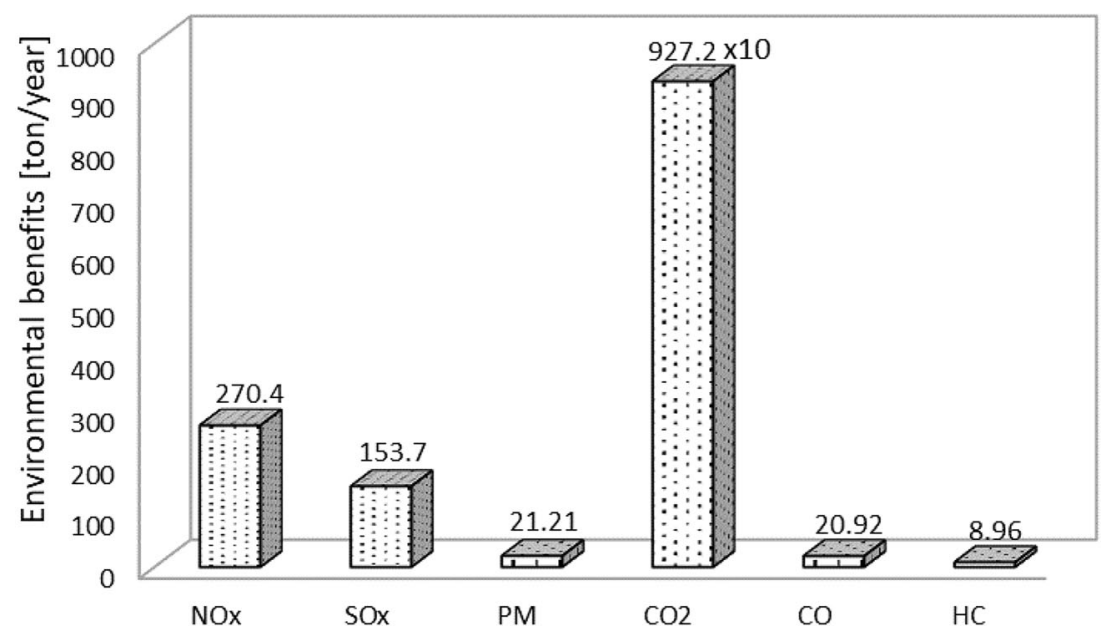


emissions. This is because of the high percent of carbon in the used heavy fuel oil used. The second-high reduced emission species is the $\mathrm{NO}_{x}$ emissions due to the high nitrogen percent in the air during burning of marine fuel in the diesel engine of the ship.

\section{Economic results}

Using the data collected about $\mathrm{M} / \mathrm{V}$ Wadi Alkarm regarding sailing periods, and fuel prices, Fig. $12 \mathrm{a}$ presents various scenarios for the annual CAPEX cost in case of applying the proposed system onboard the ship. Cases I, II, and III show the variation of the annual Flettner turbine cost (AFTC) with the expected ship's working years, after installation of the rotors onboard, at different interest values. The number of working years plays a role in reaching the minimum value of annual capital cost. The AFTC value for the present study will be about
$\$ 399,978, \$ 517,212$, and $\$ 650,463$ per year, assuming annual interest rates of $5 \%, 10 \%$, and $15 \%$, respectively.

Moreover, Fig. 12b presents the value of ship's annual saving cost due to installation of Flettner turbines onboard, which is achieved because of reducing the annual ship's fuel consumption, at different scenarios of fuel price trends. The figure implies the possibility of achieving variable annual saving cost, which could reach to $\$ 1.30$ and $\$ 3.29$ million by the end of the determined project's lifetime, at 5\% and $10 \%$ increment percentages, respectively. However, this value would account only $\$ 175,000$ if the fuel price showed a dramatic annual decrease by $5 \%$. On the other side, Fig. 13 presents the net saving value (NSV) at different economic scenarios for the proposed concept. Case (b) presents NSV for the selected case study at the current fuel price, case (a) presents NSV with an expectation of fuel price increment by $10 \%$; however, case (c) presents NSV with an expectation of fuel price reduction by $5 \%$.
Fig. 12 a Flettner rotors annual capital cos. b Ship's annual saving cost
Fig. 13 Ship's net saving value and payback period

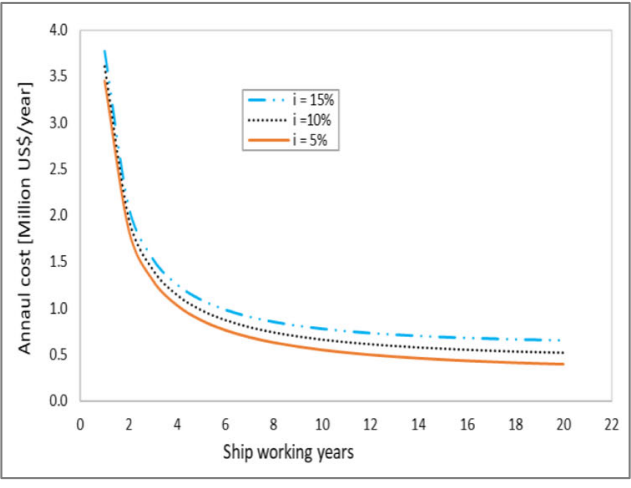

(a)

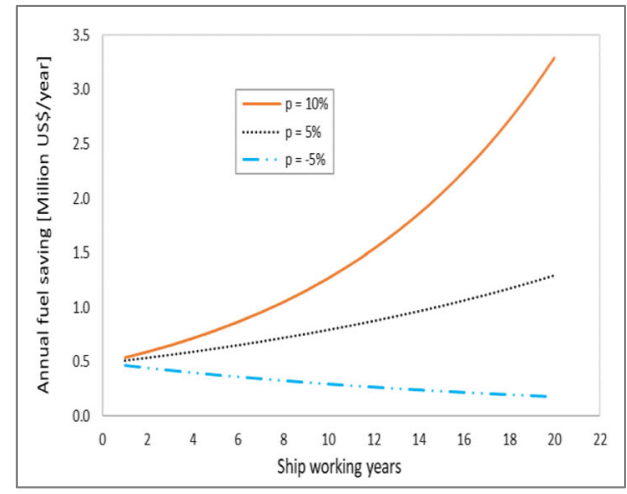

(b)

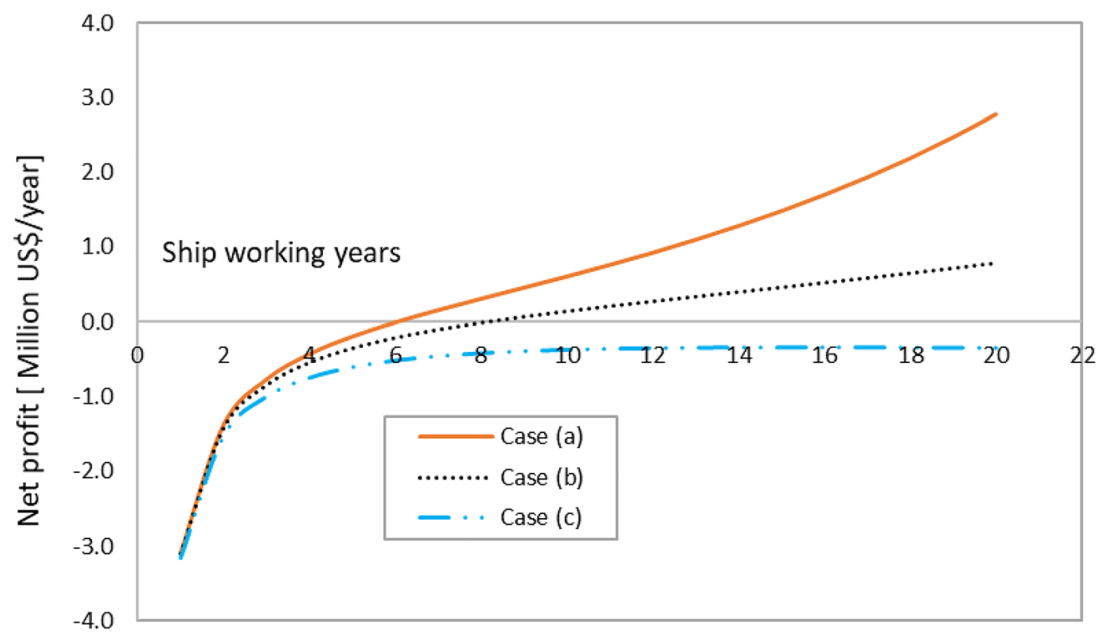


From Fig. 13, the proposed concept will be able to support the ship's operating costs after 6 and 8 working years for case (a) and case (b), respectively. On the other hand, with the condition of case (c), the project will be economically useless regardless of the ship's age. With reference to LCOE, Fig. 14 shows the tendency of this value at different conditions. Case I presents the value of LCOE for the case study with $\$ 0.05 / \mathrm{kWh}$ after 8 years of operation. Case II presents the effect of occurrence of an evolution in the turbine industry, which in turn will affect the cost of manufacturing and the accompanying reduction in the annual cost of the project. The current cost for one of the proposed Flettner rotors is $\$ 750,000$ (GL-MEEP 2019). It can be noticed that a reduction in Flettner turbine cost by one third will lead to a reduction in LCOE by $30 \%$.

However, case III presents the effect of decreasing the annual ship's sailing days, which may have occurred due to the impact of a slowdown in the growth of the global economy.
The figure shows that an accordance of decreasing the ship sailing period by $20 \%$ will increase the value of LCOE by $26 \%$. This implies that applying the renewable energy onboard ships is sensible by the surrounding international events just as it is happening now with COVID-19.

Figure 15 shows the cost-effectiveness in case of applying Flettner turbines for the selected ship. Depending on the current prices of marine fuel oils, the used heavy fuel oil price onboard the selected ship is $\$ 300 /$ ton (Bunkerworld 2020). Consequently, the cost-effectiveness values for $\mathrm{NO}_{x}$ and $\mathrm{CO}_{2}$ emissions are 1912 and $\$ 55.78 /$ ton, respectively, at an annual interest rate of $10 \%$.

The Flettner rotor cost-effectiveness values agree with the same values that could be achieved from other technologies for the identical target (Ammar 2018; Ammar and Seddiek 2017). These results can be considered as a reasonable outcome in the way of applying more attractive renewable energy sources onboard ships.
Fig. 14 Levelized cost of energy vs ship's working years at different scenarios

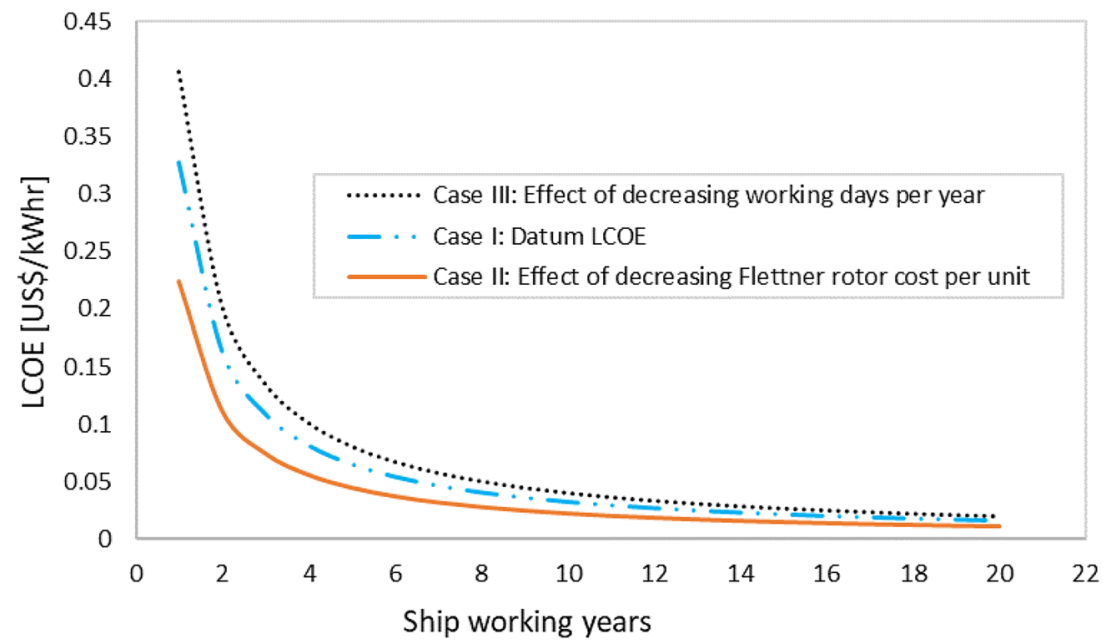

Fig. 15 Annual emissionreduction cost-effectiveness for Flettner rotors

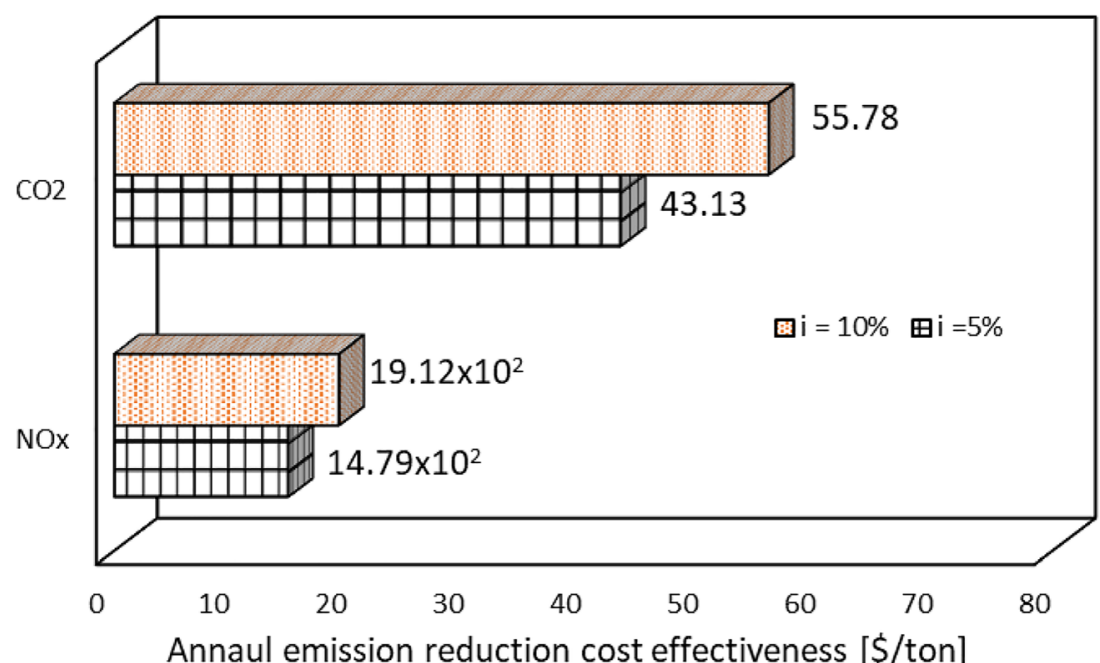




\section{Conclusions}

Zero-emission ships are the future target of the international maritime organization. With emphasis on wind power source, a literature review of the previous and current Flettner rotors powered ships in addition to the published researches is introduced. A simple model including the main technical features and the environmental and economic aspects is presented. The main conclusions can be summarized as follows:

- From a technical point of view, ship course and wind speed and directions are the main factors that affect the net output power from the Flettner rotors. Based on the selected case study, ship route, and Flettner model, the average net output power for each rotor will be $384 \mathrm{~kW} / \mathrm{h}$.

- From an environmental point of view, the optimum wind angles, for the selected rotor model, corresponding to the highest emission reduction percentages are $120^{\circ}$ and $240^{\circ}$. For the case study, using the Flettner rotors onboard the ship will reduce the fuel consumption by $22.28 \%$. In addition, the $\mathrm{NO}_{x}$ and $\mathrm{CO}_{2}$ emissions will be reduced by 270.4 and 9272 ton/year with cost-effectiveness of $\$ 1912$ and $\$ 55.8 /$ ton, respectively, at annual interest rate of $10 \%$.

- From the economic viewpoint, various scenarios are taken to assist factors that affect this technology, to expect the annual capital cost, and to determine the payback period. The annual cost of the proposed concept will be $\$ 399,978, \$ 517,212$, and $\$ 650,463$ per year at interest rate values of $5 \%, 10 \%$, and $15 \%$ respectively. The selected rotors will be able to support the ship's economy after six working years. Moreover, a considerable levelized cost of energy value is achieved.

- Finally, fossil fuel is becoming scarce, and future international legislations concerning with the maritime environment will push and accelerate the process of shifting to the renewable and the green power systems for shipping.

Author contribution Ibrahim S. Seddiek: data curation, writing-original draft preparation, methodology, visualization, investigation, writingreviewing and editing. Nader R. Ammar: conceptualization, methodology, software, visualization, investigation, writing — reviewing and editing.

Data availability Data sharing is not applicable to this article as no datasets were generated or analyzed during the current study.

\section{Declarations}

Ethical approval Not applicable

Consent to participate Not applicable

Consent to publish Not applicable

Competing interests The authors declare that they have no competing interests.

\section{References}

Abbot IH, Von Doenhoff AE (1959) Theory of wing sections. Dover Publications, Mineola

Abdelkhalek H, Han DF, Gao LT, Wang Q (2014) Numerical estimation of ship resistance using CFD with different turbulence model. Adv Mater Res 1021:209-213

Aldersey-Williams J, Rubert T (2019) Levelised cost of energy - a theoretical justification and critical assessment. Energy Policy 124: 169-179

Ammar, N.R., 2018. Energy- and cost-efficiency analysis of greenhouse gas emission reduction using slow steaming of ships: case study RO-RO cargo vessel. Ships Offshore Struct 13 (8), 868-876.

Ammar NR (2019a) Environmental and cost-effectiveness comparison of dual fuel propulsion options for emissions reduction onboard LNG carriers. Brodogradnja/Shipbuilding 70(3):61-77

Ammar NR (2019b) An environmental and economic analysis of methanol fuel for a cellular container ship. Transp Res Part D: Transp Environ 69:66-76

Ammar NR, Seddiek IS (2017) Eco-environmental analysis of ship emission control methods: case study RO-RO cargo vessel. Ocean Eng 137:166-173

Ammar NR, Seddiek IS (2018) Thermodynamic, environmental and economic analysis of absorption air conditioning unit for emissions reduction onboard passenger ships. Transport Res D 62:726-738

Ammar NR, Seddiek IS (2020) An environmental and economic analysis of emission reduction strategies for container ships with emphasis on the improved energy efficiency indexes. Environ Sci Pollut Res 27:23342-23355

Arief IS, Santoso A, Azzam A (2018) Design of Flettner rotor in container carrier 4000 DWT with CFD. Int J Mar Eng Innov Res 2(2):133139

Badalamenti, C., Prince, S. (2008). Effects of endplates on a rotating cylinder in crossflow, In: 26th AIAA applied aerodynamic conference, Honolulu, Hawai.

Ballini F, Ölçer AI, Brandt J, Neumann D (2017) Health costs and economic impact of wind assisted ship propulsion. Ocean Eng 146: 477-485

Bentin M, Zastrau D, Schlaak M, Freye D, Elsner R, Kotzur S (2016) A new routing optimization tool-influence of wind and waves on fuel consumption of ships with and without wind assisted ship propulsion systems. Transport Res Procedia 14:153-162

Bethwaite F (2013) High performance sailing: faster racing techniques. Bloomsbury, London

Bordogna G, Muggiasca S, Giappino S, Belloli M, Keuning JA, Huijsmans RHM (2020) The effects of the aerodynamic interaction on the performance of two Flettner rotors. J Wind Eng Ind Aerodyn 196:104024

Bordogna G, Muggiasca S, Giappino S, Belloli M, Keuning JA, Huijsmans RHM, van 't Veer AP (2019) Experiments on a Flettner rotor at critical and supercritical Reynolds numbers. J Wind Eng Ind Aerodyn 188:19-29

Bouman EA, Lindstad E, Rialland AI, Strømman AH (2017) State-ofthe-art technologies, measures, and potential for reducing GHG emissions from shipping - a review. Transp Res Part D: Transp Environ 52:408-421

Bunkerworld. 2020. Bunkerworld. Fuel prices. Available: http://www. bunkerworld.com/prices/ (Accessed 29 October 2020).

Cimbala, J.M., Cengel, Y.A., (2013). Fluid mechanics fundamentals and applications, 3rd Edition. McGraw-Hill Education.

Clodic, G., Gilloteaux, J.C., Babarit, A., (2018) Wind propulsion options for energy ships. 1st ASME International Offshore Wind Technical Conference, San Francisco, United States. 
Crist, P. (2009). Greenhouse gas emissions reduction potential from international shipping. Joint Transport Research Centre of the OECD and the International Transport Forum, No. 2009 - 11. 5.

De Marco A, Mancini S, Pensa C, Calise G, De Luca F (2016) Flettner rotor concept for marine applications: a systematic study. Int J Rotat Mach 2016:3458750

Elgohary MM, Seddiek IS, Salem AM (2014) Overview of alternative fuels with emphasis on the potential of liquefied natural gas as future marine fuel. Proc Instit Mech Eng Part M 229(4):365-375

FleetMon. 2020. Wadi Alkarm ship. Available: https://www.fleetmon. com/vessels/wadi-alkarm_9460760_2148389/?language $=$ en (Accessed 12 May 2020). (Accessed).

Garzón F, Figueroa A (2017) The study on the flow generated by an array of four Flettner rotors: theory and experiment. Appl Math 8:18511858

Ghenai C, Bettayeb M, Brdjanin B, Hamid AK (2019) Hybrid solar PV/ PEM fuel cell/diesel generator power system for cruise ship: a case study in Stockholm, Sweden. Case Stud Thermal Eng 14:100497

GL-MEEP. 2019. Global maritime energy efficiency partnerships. Flettner Rotors. Available: https://glomeep.imo.org/technology/ flettner-rotors (Accessed 20 March 2020).

Gupta Y, Dumon J, Hably A (2017) Modeling and control of a Magnus effect-based airborne wind energy system in crosswind maneuvers. IFAC-PapersOnLine 50(1):13878-13885

Halff A, Younes L, Boersma T (2018) The likely implications of the new IMO standards on the shipping industry. Energy Policy 126:277286

Houghton, E.L., Carpenter, P.W., Collicott, S.H., Valentine, D.T., 2017. Chapter 7 - wing theory, in: Houghton, E.L., Carpenter, P.W., Collicott, S.H., Valentine, D.T. (Eds.), Aerodynamics for Engineering Students (Seventh Edition). Butterworth-Heinemann, pp. 449-523.

IMO (2018) Report of the Working Group on Reduction of greenhouse gas emissions from ships. MEPC 72/WP.7. London.

IMO (2019) Draft report of the Marine Environmental Protection Committee on its seventy-fourth session. MEPC74/WP1 London 17 May.

Jiang B, Li J, Gong C (2018) Maritime shipping and export trade on "Maritime Silk Road". Asian J Shipp Logist 34(2):83-90

Joung T-H, Kang S-G, Lee J-K, Ahn J (2020) The IMO initial strategy for reducing Greenhouse Gas(GHG) emissions, and its follow-up actions towards 2050. J Int Maritime Safety Environ Aff Shipping 4(1):1-7

Kray T, Franke J, Frank W (2012) Magnus effect on a rotating sphere at high Reynolds numbers. J Wind Eng Ind Aerodyn 110:1-9

Kray T, Franke J, Frank W (2014) Magnus effect on a rotating soccer ball at high Reynolds numbers. J Wind Eng Ind Aerodyn 124:46-53

Lele, A., Rao, K.V.S., 2017. Net power generated by Flettner rotor for different values of wind speed and ship speed, 2017 International Conference on Circuit ,Power and Computing Technologies (ICCPCT), pp. 1-6.

Marine Traffic. 2020. Wadi Alkarm bulk carrier ship. Available: https:// www.marinetraffic.com/en/ais/details/ships/shipid:748390/mmsi: 622121414/imo:9460760/vessel:WADI ALKARM (Accessed 12 May 2020). (Accessed).

Meteoblue. 2020. Wind speed and characteritics. Available: https://www. meteoblue.com/en/weather/historyclimate/climatemodelled (Accessed 11 May 2020). (Accessed).

Mittal S, Kumar B (2003) Flow past a rotating cylinder. J Fluid Mech 476:303-334

Mohseni SA, van Hassel E, Sys C, Vanelslander T (2019) Economic evaluation of alternative technologies to mitigate sulphur emissions in maritime container transport from both the vessel owner and shipper perspective. J Shipping Trade 4(1): 15

Munson, B., Young, D., Okiishi, T., 2012. Fundamentals of fluid mechanics, seventh edition. Hoboken, NJ :John Wiley \& Sons, Inc.
Nakayama Y, Boucher RF (1998a) 4 - Fundamentals of flow. In: Nakayama Y, Boucher RF (eds) Introduction to Fluid Mechanics. Butterworth-Heinemann, Oxford, pp 41-54

Nakayama Y, Boucher RF (1998b) 6 - Flow of viscous fluid. In: Nakayama Y, Boucher RF (eds) Introduction to Fluid Mechanics. Butterworth-Heinemann, Oxford, pp 82-110

Norsepower. (2015). Rotor Sails installed onboard M/V Estraden. Available: https://www.norsepower.com/ro-ro/ (Accessed 11 May 2020).

Norsepower. (2018). Norsepower rotor sail solution. Available: http:// wind-ship.org/wp-content/uploads/2018/08/Norsepower-RotorSail-Solution-brochure-2018.pdf (Accessed 12 May 2020).

Parker, J. (2013) Future ship powering options - exploring alternative methods of ship propulsion. Royal Academy of Engineering.

Pasha J, Dulebenets MA, Kavoosi M, Abioye OF, Theophilus O, Wang H, Kampmann R, Guo W (2020) Holistic tactical-level planning in liner shipping: an exact optimization approach. J Shipping Trade $5(1): 8$

Pearson, D. (2014) The use of Flettner rotors in efficient ship design. RINA, Royal Institution of Naval Architects - Influence of EEDI on Ship Design 2014, 162-169.

Pezzotti S, Mora VN, Andrés AS, Franchini S (2020) Experimental study of the Magnus effect in cylindrical bodies with 4, 6, 8 and 10 sides. $\mathrm{J}$ Wind Eng Ind Aerodyn 197:104065

Sadek I, Elgohary M (2020) Assessment of renewable energy supply for green ports with a case study. Environ Sci Pollut Res 27(5):55475558

Scott J, Smith T, Rehmatulla N, Milligan B (2017) The promise and limits of private standards in reducing greenhouse gas emissions from shipping. J Environ Law:1-32

Searcy T (2017) Harnessing the wind: a case study of applying Flettner rotor technology to achieve fuel and cost savings for Fiji's domestic shipping industry. Mar Policy 86:164-172

Seddiek IS (2016) Application of fuel-saving strategies onboard highspeed passenger ships. J Mar Sci Technol 21(3):493-500

Seddiek IS (2017) Viability of using engine room simulators for evaluation machinery performance and energy management onboard ships. Intl J Maritime Eng 161(Part A3):283-291

Seifert J (2012) A review of the Magnus effect in aeronautics. Prog Aerosp Sci 55:17-45

Swanson WM (1961) The Magnus effect: a summary of investigations to date. J Basic Eng 83(3):461-470

Talluri L, Nalianda DK, Giuliani E (2018) Techno economic and environmental assessment of Flettner rotors for marine propulsion. Ocean Eng 154:1-15

Tillig F, Ringsberg JW (2020) Design, operation and analysis of windassisted cargo ships. Ocean Eng 211:107603

Traut M, Gilbert P, Walsh C, Bows A, Filippone A, Stansby P, Wood R (2014) Propulsive power contribution of a kite and a Flettner rotor on selected shipping routes. Appl Energy 113:362-372

UNCTAD (2019). Review of Maritime Transport 2019. United Nations Conference On Trade and Development. Available: https:/unctad. org/en/PublicationsLibrary/rmt2019_en.pdf (Accessed 20 August 2020).

Welaya YMA, El Gohary MM, Ammar NR (2011) A comparison between fuel cells and other alternatives for marine electric power generation. Int J Naval Architect Ocean Eng 3(2):141-149

Welaya YMA, Mosleh M, Ammar NR (2013) Thermodynamic analysis of a combined gas turbine power plant with a solid oxide fuel cell for marine applications. Int J Naval Architect Ocean Eng 5(4):529-545

Zdravkovich MM (1997) Flow around circular cylinders. Fundamentals 1:566-571

Publisher's note Springer Nature remains neutral with regard to jurisdictional claims in published maps and institutional affiliations. 